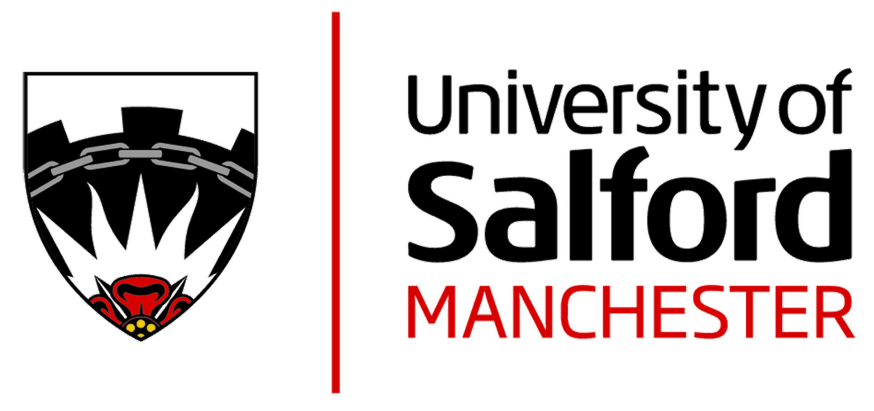

\title{
Theo Angelopoulos's O Thiasos/The Travelling Players (1975) and Oi Kynigoi/The Hunters (1977) and how they affect the Brechtian Project
}

Kosmidou, SE

\begin{tabular}{|l|l|}
\hline Title & $\begin{array}{l}\text { Theo Angelopoulos's O Thiasos/The Travelling Players (1975) and Oi } \\
\text { Kynigoi/The Hunters (1977) and how they affect the Brechtian Project }\end{array}$ \\
\hline Authors & Kosmidou, SE \\
\hline Type & Article \\
\hline URL & This version is available at: http://usir.salford.ac.uk/43600/ \\
\hline Published Date & 2017 \\
\hline
\end{tabular}

USIR is a digital collection of the research output of the University of Salford. Where copyright permits, full text material held in the repository is made freely available online and can be read, downloaded and copied for non-commercial private study or research purposes. Please check the manuscript for any further copyright restrictions.

For more information, including our policy and submission procedure, please contact the Repository Team at: usir@salford.ac.uk. 


\title{
Theo Angelopoulos's $O$ Thiasos/ The Travelling Players (1975) and Oi Kynigoi/The Hunters (1977) and How They Affect the Brechtian Project
}

\author{
Eleftheria Rania Kosmidou
}

\begin{abstract}
Theo Angelopoulos's The Travelling Players (1975) and The Hunters (1977) have been widely characterized as Brechtian mainly because of the filmmaker's use of defamiliarization effects ( $V$-effects) and the disrupted chronology in these films, but without close attention to the cinematic ways in which these films inflect, expand, and critique Brechtian aesthetics. Angelopoulos makes use of Brechtian techniques that invite spectatorial contemplation. In contrast to Brechtian epic theater, however, these two Angelopoulos films aesthetically and ideologically are characterized by melancholy and pessimism as opposed to Brecht's optimism and progressive view. After exploring the concept of left-wing melancholy, on the one hand, and Brechtian aesthetics, on the other, specifically Brecht's recommendations for a critically engaging theater that makes the audience think and respond, this article studies The Travelling Players and The Hunters in relation to Brechtian aesthetics to argue that they offer a cyclical view of history representative of left-wing melancholy as opposed to a teleological, progressive Brechtian view.
\end{abstract}

\section{Introduction}

Bertolt Brecht and his aesthetics are an established methodological way of understanding and valuing Theo Angelopoulos's work. Indeed, several scholars have characterized the cinema of Angelopoulos as Brechtian and devoted much attention to its Brechtian defamiliarization (Verfremdung) effects, commonly known as V-effects. For example, Isabelle Jordan argues that The Travelling Players is an epic film "exactly in the same way as the non-Aristotelian 
Brechtian theatre is considered epic" $(2000,232)$. She goes on to point out how the filmmaker presents important historical facts in the film by focusing on unknown people and side events; how he provides no psychological explanation about the characters; and how he uses songs in a Brechtian manner (2000, 233-240). In the same way, Barthélémy Amengual proclaims that "there is a lot of Brecht" in Angelopoulos's cinema $(2012,27)$, while Sylvie Rollet states that Angelopoulos "adopts a dramaturgical concept similar to Brecht's 'epic theatre'” (2012, 54). Finally, Ángel Quintana $(2012,160)$ discusses Angelopoulos's "image-symbol" and use of epic theatre in order to conclude that the filmmaker "searches for a way to interpret the main characteristics of the epic theatre in cinematic representation."

Writing The Films of Theo Angelopoulos: A Cinema of Contemplation in the late 1990s, Andrew Horton's tendency to interpret Brecht's positions by positing a binary approach that places empathy as opposed to estrangement, or didacticism as opposed to reflection, paved the way for such oversimplified Brechtian readings of the filmmaker's work. In a few surprising instances that are important for our purposes here, however, Horton broke away from his binary interpretations of Brechtian aesthetics when he claimed that while "Angelopoulos often refers to Brecht," and the films themselves cause "the audience to think" (Horton 1997, 14) critically and react, they also engage the audience emotionally and so break the Brechtian alienation effect through the mixture of theatricality and reality in his films (14-15). Yet there is a contradiction inherent in Horton's argument. The supposed Brechtian distance between thinking and feeling is lost in much of Angelopoulos's work precisely through its theatricality, namely, his use of Brechtian ideas of theater and stylization-and not through cinematic naturalism or the "phenomenological realism of the photographic image" (Rollet 2012, 60), that is, the creation of illusionary images of the world, which Brecht opposed.

With this widespread scholarly tendency-arguably influenced by Horton's contradictory argument-to characterize Angelopoulos's cinema as Brechtian in mind, I wish to discuss his O Thiasos/The Travelling Players (1975) and Oi Kynigoi/The Hunters (1977) to consider not only how far these films may be identified as Brechtian but also how the cinematic uses of Brechtian devices expand, critique, and inflect Brechtian aesthetics. I focus on two formal aspects of these films: the V-effects and episodic narrative, Brechtian formal devices that not only destabilize but also at the same time interrogate historical representation. I argue that in these two films, the filmmaker drastically rewrites Brechtian aesthetics, adding political passivity to the critical category 
of defamiliarization by way of melancholy and pessimism, which I will prove to be part of Angelopoulos's cyclical view of history.

I am not the first critic to observe the leading role that melancholy plays in offsetting Brechtian effects in Angelopoulos's films. David Bordwell was the first to note that Angelopoulos's cinema is melancholic, contrasting this to Brechtian optimism and progressiveness, two aspects of Brechtian aesthetics which I explore in the next section. Bordwell's intriguing exploration of Angelopoulos's cinematic style concedes that dedramatization (the muting of the flow of drama within a scene) as well as the use of Brecht's "estrangement effect" in Angelopoulos's early films are achieved through a mise-en-scène that favors a distanced, non-centered frame and planimetric composition: friezelike composition that combines both frontal and profile views-devices that many critics have interpreted as Brechtian (Bordwell 2005, 172). However, for Bordwell, Angelopoulos's style is not optimistic but rather melancholic. As he argues, "by playing out his dramas in vast landscapes he recalled Jancsó, but instead of the exuberant rolling expanse of the Hungarian plains, Angelopoulos offered rocky mountainsides and overcast landscapes: landscapes that exuded mournfulness" $(2005,159)$. It is not only the bleak landscapes in his films but also the filmmaker's use of long takes that point to melancholy (2005, 184). Nevertheless, despite his insightful characterization of the filmmaker's cinema as melancholic, Bordwell offers a Brechtian reading of Angelopoulos's cinema when he states that "by concentrating on groups and by staging in a manner at once minimalist and monumental, Angelopoulos blocks traditional paths to empathy. This yields a critical detachment that in turn invites us to reflect on the larger historical forces at work in a situation" $(2005,184)$. Hence, there is a gap between the melancholy Bordwell identifies and the Brechtian conclusions of detachment that he draws.

Vrasidas Karalis's discussion of Ulysses' Gaze and Angelopoulos's work in general also insightfully characterizes Angelopoulos's cinema as both partly Brechtian and melancholic. Karalis takes issue with Horton's contradictory argument that "the mixture of theatricality and reality in his films often leads us into a deeper, fuller emotional bond with the film-one that, we could say, embraces our thinking mind as well" (Horton 1997, cited in Karalis 2006, 252). He points to the paradoxical aesthetics that emerge in Angelopoulos's films "in the creative synergy between the empathy given by a story and the critical distance established by the director's stance" (Karalis 2006, 268). Like Bordwell, he taps into melancholia when he talks about Angelopoulos's characters in his films: "One could even claim that some of his central characters are indeed Quixotic, half tragic and half comic, unable to come to terms with 
the history around them. This gives sometimes the impression of a fin de siècle melancholia or post-communist pessimism, or even from the point of view of his country a kind of elegiac farewell to a lost innocence" (Karalis 2006, 255). His focus remains on Angelopoulos's visual fields. For Karalis, the Brechtian V-effects in Angelopoulos's work are evidenced in the camerawork that avoids identification with the character, as it is always in deep focus, ignores empathic close-ups, and "moves parallel to its subject" $(2006,257)$. At the same time, he argues that the camerawork also generates Aristotelian cathartic empathy created by the filmmaker's distinct melancholic use of color $(2006,263)$. Karalis and Bordwell see both Brecht and melancholia in Angelopoulos's work, with Karalis concentrating on the filmmaker's departure from Brecht in his use of color, and Bordwell on his bleak landscapes and long takes.

Drawing on the observation in these two critical works of the tension between the Brechtian aesthetics and melancholic aspects of Angelopoulos's cinema, I argue that while Angelopoulos makes use of Brechtian techniques that alienate the audience and invite spectatorial contemplation, he adopts a pessimistic, melancholic lens, which is in direct contrast to the progressive view of history in Brechtian epic theater. I will show the ways in which in O Thiasos/ The Travelling Players and Oi Kynigoi/The Hunters (1977), two films considered by many to be his most Brechtian works, cannot be characterized as ideologically Brechtian. On the contrary, they form prime examples of a particular kind of melancholy. It is not only the melancholic landscapes, muted dramas, or, as Bordwell cleverly notes, the use of decentring framing within the very long takes that point to Angelopoulos's melancholy $(2005,184)$. Nor is it only the use of melancholic colors that lead to emotions of identification, as Karalis argues. The filmmaker's melancholy lies rather in his pessimistic view of history, which is shown allegorically in his cyclical use of the camera and cyclical narratives that are caught up in the past and go round and round. It is not a melancholy in a general sense but a "left-wing melancholy" (Benjamin [1931] 1974), a melancholy specifically connected to left-wing politics, derived from a disappointment with the left in Greece, which drastically alters the Brechtian aspects of his films.

\section{Left-wing melancholy}

Freud's "Mourning and Melancholia" introduced a connection between melancholy and the attachment to a lost past and the refusal to acknowledge the present. According to Freud, melancholy captures the self's attachment to a lost object and renders it incapable of moving on into the process of 
working-through. Mourning, on the contrary, involves a process of working-through, which eventually allows the individual to engage with the present (Freud 1917, 243-258). Walter Benjamin later connected Freud's notion of melancholy with a left-wing "fatalism" ([1931] 1974, 28) in his fierce critique of Erich Kästner's poetry in his 1931 essay "Left-Wing Melancholy (On Erich Kästner's New Book of Poems).” In the essay, Benjamin criticizes Kästner's work as being pretentiously revolutionary in its left-wing aspirations, since it proclaims a hatred towards the petit bourgeoisie, even though it "has itself an all too intimate petit bourgeoisie flavour," and its popularity "is linked to the rise of a stratum which took unveiled possession of its economic power positions" ([1931] 1974, 28). Benjamin's critique was not limited to Kästner; rather, it was pointedly aimed at other left radical intellectuals of the time, such as Walter Mehring and Kurt Tucholsky, whose proclaimed left-wing radicalism left no space for action because their nihilism and despair derived from their "[t]ortured stupidity" (Benjamin [1931] 1974, 31). For Benjamin, this was a form of melancholy peculiar to the left. Benjamin's "left-wing melancholy," then, is similar to Freud's melancholy in its inability to work through the past but different in its specific connection to left-wing politics. In politics, it is the cause and effect of attachment to a failed "left-wing radicalism" that precludes looking for radical possibilities for "political action" in the present. According to Benjamin, left-wing melancholy is "complacency," "fatalism," and "constipation" ([1931] 1974, 31): it can only lead to political passivity and inaction in the present.

Benjamin's notion of left-wing melancholy acquired new significance in the last decade of the twentieth century. In his interesting, innovative analysis of mourning and melancholy in Benjamin's work, Max Pensky's Melancholy Dialectics: Walter Benjamin and the Play of Mourning (1993) offers a careful reading of the intersection of melancholy and critique that is of relevance to the current study for its identification of a tension between dialectical thought and allegory. For Pensky, there is a dialectical dimension that can be teased out of Benjamin's melancholia. On the one hand, Benjamin's critique of left melancholy poses a critical challenge to the melancholic mind, namely, to act against melancholy. On the other, his notion of allegory always implies the presence of melancholy that cannot be overcome. As Pensky notes, in Benjamin's later mature writings on the dialectical image, we can deduct that the allegorical mind is always melancholic and results in political passivity, while the dialectical mind is defined in explicit contrast to passivity (1993, 211-212). Pensky's work is important here, as he shows how melancholy is folded into Benjamin's notion of allegory. He offers a more nuanced reading of Benjamin's 
notion and its link to melancholy by introducing the term "melancholy dialectics." His melancholy dialectics puts emphasis on the political power of the dialectical image as opposed to melancholic allegory and left-wing melancholy, which are always politically passive. "Only by overcoming melancholy allegory first can the dialectical image acquire any political relevance," he argues (Pensky 1993, 231). In my proposed reading of Angelopoulos's films, melancholic allegory is not overcome, and the left-wing melancholy evident in these films poses a challenge to the audience to overcome melancholy and thus respond in a Brechtian way.

Important for the purposes of this paper is also Richard Dyer's application of the term left-wing melancholy to cinema. Looking at Rainer Werner Fassbinder's films, Dyer identifies the evidenced melancholy in Fassbinder's films as

left-wing-and not just a general despair at the human condition-because it sees the specifically (historically determinant) capitalist source and character of misery in contemporary society and observes how the weight of oppression lies on the working class. In its "melancholy," however, it does not see the working class as the agent of historical change-instead it stresses the working class as the victim of capitalist society and/or as hopelessly complicit in its own oppression. (Dyer 1976, 55-56)

As Dyer explains, Fassbinder's left-wing melancholy is clearly shown in the emphasis on people as victims of society and history. It is this focus on victims who are defeated and unable to resist or revolt without "being brutalised by the forces that seek to brutalise" which Dyer contends "implies a model of social change that is unable to indicate how people can be actively involved in that process of change-in other words, a model that makes political struggle pointless" $(1976,60)$.

We have then a range of uses of "left-wing melancholy" as a term that moved from Germany in the 1930s to the US in the 2000s to talk about various forms of cultural production as well as political positionings across divides of place, language, and time. In what follows, I use the term left-wing melancholy to talk about Angelopoulos's films made in Greece in the 1970s, which brings us to yet another place, language, medium, and time. I find it to be particularly relevant since the two films discussed here deal with the Greek Civil War from a left-wing perspective. Does Angelopoulos use Brechtian techniques in his films? Yes, and I am not alone in this judgment, as we have seen. Does the filmmaker offer critical intellectual detachment and reflections on the characters and situations depicted in these films, a detachment that makes the spectator respond in a Brechtian progressive way? I believe no, precisely because he 
does not offer a way out of these situations. My argument fills in what I believe has been a gap in the critical readings of Angelopoulos's Brechtian aesthetics. For the purposes of the argument, I present an overview of what I mean by Brechtian aesthetics before I examine these aesthetics in relation to the films.

\section{Brecht and the historicizing theater}

Brecht argued for a historicizing or epic theater. While Brecht thought himself a realist, he was against realistic representations; indeed, he advocated for theatricality and stylization. In "Against Georg Lukács," Brecht explains:

Our concept of realism must be wide and political, sovereign over all conventions. Realistic means: discovering the casual complexes of society/unmasking the prevailing view of things as the view of those who are in power/writing from the standpoint of the class which offers the broadest solutions for the pressing difficulties in which human society is caught up/emphasizing the element of development/making possible the concrete, and making possible abstraction from it. (Brecht 1980, 82)

Brecht argued against the setting up of false situations and attitudes towards the world. He advocated a historicizing (epic) theater in order to unmask social realities and to show the audience that the world is alterable. For Brecht, the purpose of epic theater is to educate people, to make the audience think critically as the audience becomes the observer of the events that take place on stage. Brecht's didacticism was directed towards socialism. ${ }^{1}$

For Brecht $(1964,97)$, historicizing or epic theater must focus wholly on whatever is unique and extraordinary in everyday events and thus demands exploration. Brecht saw what he called Aristotelian theater to have a linear development, to foreground feelings and the plot, and to implicate the spectator emotionally in a stage situation. By contrast, Brecht's historicizing or epic theater should have a nonlinear development, focus on reason, and prioritize narrative over plot; it should not implicate the spectator emotionally but turn him or her into an observer $(1964,37)$. Brecht's dislike for the representation of historical phenomena in a dramatic manner stems from his idea of history as changeable and thus progressive: "Human behaviour is shown as alterable; man himself as dependent on certain political and economic factors and the same time as capable of altering them" $(1964,86)$. Accordingly for Brecht, "the concern of the epic theater is thus eminently practical $(1964,86)$ : it is instructive and didactic in the sense that its purpose is to make the spectator think; to distance him or her in a certain direction so that he or she can criticize what 
is presented on stage; and to instruct him or her how to discover the means to change the world towards a better one $(1964,72-75)$. It should be noted that Brecht's didacticism is a critical one (Jameson 1980, 206), since from epic theater, the spectator gains "a new perspective of knowledge from which the old way is scrutinized" (Polan 1985, 670). Recent discussions of Brecht in theater studies have questioned the strict binarism in Brecht's thought-namely, of detachment as opposed to empathic identification-and have shown that the notion of empathy is in fact a problem in Brechtian aesthetics. As we shall see, these discussions are important here, since empathy is also a problem in Angelopoulos's use of Brechtian techniques.

Olga Taxidou argues that Brecht did not object to empathy. Rather, his objections to Aristotelian catharsis had to do with antitheatricality in the classical tragic model, whereas tragedy's purely theatrical and spectacular dimension became "a fundamental premise of his whole approach" $(2008,242)$. As mentioned above, theatricality is a fundamental premise of Angelopoulos's cinematic approach, as well, and so I want to point out this thread of revisionism in current rereadings of Brecht. Angela Curran also revisits Brecht's criticisms of Aristotelian theater and insightfully concludes that Brecht's "primary concern is with a particular use of empathy that locks the viewer into the perspective of the character and does not enable her or him to consider the action from a wider social perspective. Brecht's own works show that engaging with characters can be useful for reflecting on the social causes of suffering" (Curran 2001, 181). Brecht wanted his theater to make the audience reflect and criticize their acceptance of the social situations they live in, and his aim was to construct his plays with the use of various $\mathrm{V}$-devices to create this kind of response from the audience. Nevertheless, his aim was not to guide his audience into drawing certain conclusions offered in the play. Instead, as Curran shows, "Brechtian dramatic practices enable critical viewing, but these dramatic practices do not cause the viewer to adopt a specific stance toward the events represented" (2001, 179).

In order to engender this critical response in the viewer, a very important aspect of epic theater is to represent the dramatic and historical events as changeable (White 2004, 129). Brecht insisted that this could be achieved by presenting situations as historical: "The actor must play the incidents as historical ones. Historical incidents are unique, transitory incidents associated with particular periods. The conduct of the persons involved in them is not fixed and 'universally human'; it includes elements that have been or may be overtaken by the course of history, and is subject to criticism from the immediately following period's point of view. The conduct of those born before us is alienated from 
us by an incessant evolution" (Brecht 1964, 140). Contrary to the realistic, dramatic representation of history, Brecht maintained that the theatrical, stylized representation of everyday historical events demystifies reality and evokes critical spectatorial response and the rejection of the notion of destiny-a notion I shall return to below, as it is of importance to my analysis of the films. In Benjamin's words, the spectators' reaction to epic theater should be, "It can happen this way, but it can also happen a quite different way" (Benjamin [1966] 1998, 8). Hence, the historicizing incidents become alienated and subjected to criticism by the audience. Epic theater therefore instructs the audience and makes people react. Brecht gave special attention to the "anti-illusionist devices" (Mumford 2009,65 ), including gestus, types instead of characters, and defamiliarization (V-effects), as well as episodic narrative and fragmentation.

One of the key elements of epic theater is the nonlinear, episodic narrative, the segmentation of the text that leads to points of rupture within the text (Walsh 1981, 70). Brecht's endorsement of time discontinuity is associated with his didacticism (Van Steen 2013, 87), which is related to his idea of educating the spectators, on the one hand, and provoking the correct political response, on the other. His dialectical didacticism was progressive, directed towards socialism (Tyson 2012). The continuous shifts in time between the past and the present and the narrative disruptions help the spectator criticize the present conditions, thus establishing connections. These in turn prompt the spectator to react.

Brecht does not identify the episodic narrative as the only possible vehicle of epic theater. Defamiliarized acting and the destruction of the fourth wall in Brecht's writings are necessary devices for historicizing, epic theater. This point is important in the analysis of the films that follows, since what is at stake in the filmic techniques that approach or veer from Brechtian ones is Angelopoulos's treatment of history. As Brecht $(1965,76)$ contends: "If empathy makes something ordinary of a special event, alienation makes something special of an ordinary one. The most hackneyed everyday incidents are stripped of their monotony when represented as quite special. The audience is no longer taking refuge from the present day in history; the present day becomes history." For the purpose of defamiliarization, sentences should be delivered by the actors on the stage for criticism by the audience (Brecht 1964, 98), and the actors should not be identified with the characters (1964, 195-196). The actor should act in a way that makes it clear that he or she is being observed, which then deprives the audience of the impression that they are watching real events.

Foregrounding the theatrical, stylized performances in Brechtian theater helps the spectator to create a critical distance from the stage, and thus make 
him or her react. Jameson has rightly noted therefore that this concept of estrangement is above all political $(1980,206)$. Of course, the dialectical interaction between the audience and the actors discussed here is more complicated, if not indeed difficult, in cinema, where the two are separated by the medium itself. Nevertheless, Angelopoulos uses V-effects and dialectical interaction in his films. However, while the stylized performances in the films do at times create emotional distanciation between the spectators and the characters, at other times they do the opposite, as I will show.

\section{The Travelling Players}

From 1944 to 1945 and 1946 to 1949 , Greece was subject to a civil war. The first signs of division began during the Axis Occupation among the resistance groups. The outcome of those early struggles was decided by direct and sustained foreign interventions first by Britain in December 1944 to early January 1945, then by the United States after 1947, following the outbreak of the Cold War and the shift in the international balance of powers. The Greek Civil War was an ideological war; the issue was whether Greece after World War II would become communist or remain a Western-oriented, capitalist country. ${ }^{2}$ Angelopoulos's films take a specific stance on this historical conflict in both The Travelling Players and The Hunters. ${ }^{3}$

The Travelling Players is the third feature film made by Theo Angelopoulos. The film follows an acting troupe around Greece, from General Metaxas's dictatorship in 1936 through World War II, the Greek Civil War, and the Cold War up to the election of Greek Field Marshal Alexandros Papagos in 1952. As the troupe travels, history affects and transforms its members.

Because the film was made during a period of strict censorship under the right-wing military dictatorship (1967-1974), in order to pass the Colonels' censorship while revisiting the history of the Civil War, the filmmaker employed two main dramatic intertexts as structuring devices to mask the contemporary references-the one taken from popular nineteenth-century theater and the other from classical Greek drama. Throughout the film, the troupe attempts to perform the Greek popular melodramatic play Golpho, the Shepherdess, written by Spyros Peresiades in 1893, but each performance is interrupted. The play is about the love of a poor young woman, Golpho, and a young shepherd called Tassos. This melodramatic convention is the film's first intertext. At times, it is used to refer to the fate of the actors themselves and introduce the audience to important things that are happening to them. For example, in segment 15, a performance of the play begins. Pylades, who plays 
Tassos, is visible in profile on stage as the camera is positioned in the wings. He greets Golpho as she comes on stage, who returns his greeting, but then he asks, "are we being watched?" However, in the film's context, the line takes on an allegorical meaning, as the camera then reveals to the film audience (but not the theater audience) that two of the dictator Metaxas's secret policemen are waiting in the wings on the other side of the stage. In the next shot, the camera faces the stage. Now the viewer sees what the theater audience sees. The play is soon interrupted as Pylades runs off-stage, with the two policemen running after him. Here Pylades is in danger because of his political beliefs. The disruption of a popular play, and thus people's entertainment, by the dictatorship's policemen allegorically points to the dictatorship's disruption of political and social life, as well as to the struggles of the real drama played out in Greece at the time.

Elsewhere, Golpho, the Shepherdess is interrupted to introduce historical events. For example, in segment 21, another performance is about to begin. The curtain opens and Orestes' father, Agamemnon, appears on stage; he announces that it is 28 October 1940 and dedicates the performance to the Greek troops fighting the Italians. The play begins, but it is soon interrupted by the sound of aerial bombing. The scene ends when everybody leaves the theater and the camera faces the empty stage. The action takes place off-camera for a few minutes while explosions are heard, and the lights in the theater tremble as we are left to watch the empty stage. The sequence ends with a dissolve as the screen turns black. The interruption of the play here corresponds to Greece's entry into World War II.

Every interruption of the play in the film is caused by very specific historical and political circumstances. By interrupting the play each time in this way, the film signals that the troupe's inability to perform Golpho is due to forces its actors cannot control, making them victims rather than agents, to use Dyer's line of argument (1976). In other words, the spectators are not prompted to consider what other options the players had, as Brecht would have it. Angelopoulos situates this melodramatic intertext as part of a larger social and political framework, which is part of the Brechtian aesthetics. He does this, however, by presenting the players as victims, unable to act upon their fate and lives. This notion of fate is even more evident in the second major theatrical intertext used in the film, the Oresteia, Aeschylus's fifth-century BC cycle of tragedies based on the myth of the house of Atreus.

The use of the Oresteia, a strategy for avoiding the censors, is not explicit but only hinted at on the level of the plot and character. The only name used in the film that is associated with the myth is Orestes; however, the Atrides 
myth is the framework through which the story is told, and characters in the troupe gradually become identified with characters in the play. When the civil war breaks out, Orestes, his friend Pylades, and his friend known as the poet in the film fight on the side of the left-wingers and communists, while Orestes' sister, Electra, helps the guerrilla fighters. Orestes' mother, Clytemnestra, and another member of the troupe, Aegisthus, become lovers while Orestes' father is away. During the Axis Occupation, Aegisthus becomes an informer and betrays Agamemnon, which leads to his arrest and execution by the Germans. Later on, Orestes kills his mother and Aegisthus on stage performing Golpho, the Shepherdess, while Electra helps him to revenge his father's betrayal.

This mixing of history and myth has, of course, the effect of dehistoricizing history; what we, the audience, see in the film is a representation of events and not history itself. On another level, however, does the mixing of history and myth not suggest the futility of the events shown? Furthermore, Aeschylus's plays are about the transition from revenge to justice and the stabilization of a civic community governed by the rule of law. In the Oresteia, Orestes is judged by a group of Athenians, and in the end he is acquitted. By contrast, the myth in the film remains on the level of revenge, and justice is not delivered. Things do not change, with Orestes being executed towards the end of the film. On the one hand, the staging of history in the film points to the inevitability of the events shown. On the other, as the myth unfolds in the film, the relation between the characters in the film and the characters in the myth points to the notion of destiny.

When reading critical studies of The Travelling Players, one inevitably comes across Brecht. The Travelling Players represents a left-wing counternarrative of the Greek Civil War to the official one of its era by presenting a clearly sympathetic viewpoint of the communists in the film. Moreover, in a Brechtian way, the film encourages a meditative approach to history from the audience. However, the distinct camera movement and the nonlinear way in which the historical events are depicted in the film can offer a different view as cinematic devices that point to the filmmaker's left-wing disillusionment. To demonstrate the effects of this technique, I want to focus on three scenes that have been characterized as the Brechtian scenes par excellence in the film (Rollet 2012) and are distinguished from the rest of the film, as Angelopoulos gives them particular emphasis through his choice of mise-en-scène shots and his attention to filmic form. These are the three monologue scenes in which the characters in the troupe identified with Agamemnon, Electra, and Pylades-three characters with a long theatrical genealogy-each move out of the historical moment to deliver a monologue. These scenes are shot in medium close-ups, marking them 
as distinct from the rest of the film that is primarily framed in long shots. The fusion of theatricality with cinematicity in these scenes, their contrast with other filmic techniques in the film, and their monologues that are spoken in the first person telling stories that narrate incidents specific to these characters all impact the films' overall politics. These scenes in their content and form definitively mark the film's ideology as non-Brechtian.

In the first monologue, the troupe is on a train. As the camera observes the troupe inside the coach in a long shot, Agamemnon gets up, moves towards the camera, sits down in front of it, and starts talking. Looking straight at the camera, in a medium close-up, he talks unemotionally to the camera and hence the audience about his painful experience as a refugee from Asia Minor. The scene ends in silence with Agamemnon looking straight at the camera for a few moments. The second monologue is given by Electra by a riverbank after she has been raped. In a long shot, she gets up, cleans the dirt from her clothes, walks towards the camera, faces it, and starts talking. In a monologue deprived of emotions, she tells us how the Greek Civil War began and about the British involvement in the $\Delta \varepsilon \kappa \varepsilon \mu \beta \rho$ เava (Dekemvriana, the December events). The scene ends in a similar way. The camera stays fixed on Electra looking straight at the camera for a few moments after she has finished her monologue. The third monologue is delivered by Pylades towards the end of the film. In a medium close-up shot, and in a similarly unemotional monologue in a hotel room, he tells Electra about his imprisonment on the island of Makronissos and how the communists being tortured there were coerced into signing anticommunist declarations. He signed one. The scene ends in silence again, with the camera fixed on Pylades' face. Following Brecht, Angelopoulos arguably creates a Brechtian narrative deprived of natural or realistic performances in these monologue scenes. One cannot avoid recalling Brecht's writings on a defamiliarized, detached acting style that would awaken the spectator's intelligence and make him or her think. As Brecht notes:

The stage began to tell a story. The narrator was no longer missing, along with the fourth wall. Not only did the background adopt an attitude to the events on the stage ... but the actors too refrained from going over wholly into their role, remaining detached from the character they were playing and clearly inviting criticism of him.

The spectator was no longer in any way allowed to submit to an experience uncritically (and without practical consequences) by means of simple empathy with the characters in a play. The production took the subject matter and the incidents shown and put them through a process of alienation: the alienation that is necessary to all understanding. When something seems "the most obvious 
thing in the world" it means that any attempt to understand the world has been given up. (Brecht 1964, 71)

In Brecht's theater, the detached acting style and the bareness of the dramatic space deliberately distance the actors from the audience. Consequently, the spectators can identify neither with the dramatic development nor with the characters, since these techniques influence people's feelings and actions. For Brecht, this was a matter of political importance, since at the heart of his argument is the education of the spectator. The spectator becomes active and realizes that he/she not only must but also most importantly can change things-that the world can be changed. In the same way, the emotionless monologue scenes discussed above are theatrical in Brechtian terms in that they encourage the audience to observe from a distance, contemplate, critically react, and thus become active.

The three monologue scenes then are moments in the film when the action stops and important historical and political information is given, and all of them end in moments of chilling silence, which is meant to leave the audience time to grasp and contemplate what has been heard. However, we also hear the characters in these scenes narrate stories and situations for which nothing can be done to make things better. Moreover, their function as characters with a long genealogy in the theater implies that they are trapped by some notion of fate. In Aeschylus's trilogy, Agamemnon, Electra, and Pylades are all involved in a cycle of revenge and vengeance fated to occur. It is their destiny to encounter suffering in their lives, and they cannot escape their destiny. Through the reintroduction of drama here, Angelopoulos allegorically proposes an emotional reception of these characters by the audience crucially at the moments when the notion of destiny impacts their historical narratives, heightening their melancholia.

Angelopoulos chooses Agamemnon, who is executed by the Germans in the film because of his involvement in the resistance, to describe the events that took place in Asia Minor. Despite his hunger when they arrived in Greece, he did not eat the food offered to him by a Royalist family because of his political beliefs. His despair, loss of his family, and hunger here are juxtaposed with his left-wing aspirations. Electra, who throughout the film helps the guerrilla fighters, is then chosen to describe the negative outcome of the Dekemvriana, thus describing the futility of this fight. Finally, Pylades, who fights with Orestes alongside the communists throughout the film, is the character chosen to describe the pointlessness of the communist cause, as in the end he had to sign an anticommunist declaration in order to survive. These distinctive scenes do 
not offer any progressive solutions in a Brechtian way. The characters, with such a long theatrical genealogy, cannot escape their destiny-a helplessness which is not Brechtian. Angelopoulos proposes here a melancholic allegory as Pensky would have it, namely, a left-wing melancholy, which is always politically passive. In their mise-en-scène, these monologue scenes are distinguished from the rest of the film, as well. As Bordwell $(2005,166)$ has shown, Angelopoulos prefers distant shots, which result in dedramatization that allows for contemplation and distanciation. However, these three scenes are filmed in medium close-ups, and the three characters-Agamemnon, Electra, and Pylades-are separated by their monologues from the other characters in the film: they are individualized.

The reintroduction of drama here inflects Brechtian aesthetics in the following ways. In these monologue scenes, despite the characters' direct address, which would normally form the breaking of the fourth wall that was for Brecht a key strategy for nonidentification, they are presented psychologically in a way that fills out their barely distinguishable presence as ensemble actors in the rest of the film. The three characters talk about their inner lives and awful experiences, as well as how these have affected them. The theatrical genealogy of these characters, who cannot escape their destiny, the flatness of their narration of the historical events they have lived through, the film's very different lens on their faces, their presence and individualization, and the feeling of silence that follows contribute to creating an emotional audience involvement as opposed to a Brechtian intellectual one. We are meant to empathize with these characters here. As we have seen, Brecht did not exclude empathy from his epic theater. However, it is the mixing of emotional involvement with the notion of fate that marks a clear departure from Brechtian aesthetics in The Travelling Players.

According to Horton, there are moments when Angelopoulos's films do depart from Brechtian defamiliarization effect. However, as he paradoxically argues, and as we have seen, these moments are anchored in the theatricality, namely, the stylized and emotionless performances in Angelopoulos's films, which for Horton is the non-Brechtian element of the films (1997, 14-15). Nevertheless, the scene in which Electra is raped by right-wing men wearing masks-a scene that violates conventions of cinematic naturalism and is the most theatrically stylized scene in the film-points to the contrary. This scene is very violent, but the violence is not explicitly shown. Throughout we see the backs of the men as they rape Electra while they ask her where her brother Orestes is. The hidden violence of the rape of Electra here could also be a reference to the offstage violence of classical tragedy. This theatricality of the 
violence that eliminates the illusion of reality indeed creates the Brechtian distance necessary for us - the audience - to observe everything and reflect on it. Yet, as it happens throughout the film, no answers are given at the end of this scene; no possible solutions or possible outcomes are offered in a Brechtian way.

Indeed, it is not the theatrical, stylized elements of the film-as, for example, in the rape scene just analyzed-but the theatricality of Brechtian theater in the three monologue scenes that makes the audience feel close to the characters and sympathize with them. These emphatic and distinct monologue scenes inflect and transform Brechtian aesthetics through their melancholy and the notion of fate inherent in them. Sylvie Rollet insightfully makes the claim that Angelopoulos's cinema in general "embodies the end of ideologies" through "the absent or, rather, the mute God" $(2012,61)$.. Yet is it not the pause of history-as manifested in these scenes as well as in the episodic narrative of the film - that best externalizes melancholy and the end of ideologies?

The film's melancholy is manifested even more firmly in the filmmaker's cyclical use of camera and the disrupted chronology of the film. The clearest use of the cyclical use of camera can be seen in the 360-degree panning shot, a four-minute long take, set in a town square in which the prelude to the Greek Civil War, the Dekemvriana, is treated.

In this long shot, the camera shows us a large gathering of people. They are waving Greek, British, American, and communist flags. Suddenly, shooting is heard offscreen, and people start running away in panic while the camera remains still. Then the camera pans around and follows the people as they run away until it completes a 360-degree circle to reframe the square. It is empty now apart from five dead bodies in the middle of the square. We are left to watch the square for some time and wonder: why did this happen? Who was shooting? Next a bagpipe tune is heard. As the camera stays fixed on the square with the dead bodies, a Scottish bagpiper enters the frame, crosses the square amid the dead bodies and leaves the frame. One of the bodies stands up and runs away. The camera follows him as he disappears from the frame, then pans to the left to find a demonstration coming towards the square from a side road. The demonstrators are holding communist flags. The camera continues its pan to the left to show a demonstration arriving at the square from another side road. Then the camera follows them to give us a long shot from behind as the people gather in the square to participate in this communist demonstration. The dead bodies are still on the ground. In this famous 360-degree panning shot, shifts in time occur and the whole sequence of events of the Dekemvriana is covered in a single long take. This sequence-shot has been characterized as Brechtian (Bordwell 2005; Volpi and Barbera 2012). Yet what is the purpose 
of this cyclical movement? What functions are performed by this emphatic 360-degree panning shot, in which shifts in time occur?

In terms of form, the cyclical camera movement in this scene-which changes from a celebration of the end of the war to gunshots, victims, and divided loyalties-allegorically points to a cyclical presentation of history. Angelopoulos creates here an allegory for a cyclical view of the past, an allegory for a history that goes round and round instead of Brechtian optimism for the possibility of change. This cyclical view of history manifested in this sequenceshot, and indeed evident throughout the film, allegorically reflects a left-wing melancholy. Nothing could be more opposed to Brechtian progressiveness: it renders political action fruitless, if not utterly pointless.

This is not only evidenced in the above scene but also in the filmmaker's use of long takes throughout the film where changes in time and in place occur-the episodic narrative of the film, as Brecht would have it. Gianni Volpi and Alberto Barbera explore the use of long takes and time shifts in The Travelling Players, and they also tap into the circularity of the film, as the film ends at the beginning of the time period it spans $(2012,213)$. However, they paradoxically draw a Brechtian conclusion when they argue that at the end the protagonists are present, and this presence "(which contains their destinies that are already known to us) offers a Brechtian opportunity for reflection and the drawing of conclusions" (213). The film begins in 1952 and ends in 1936, at the start of the time period it covers. In the closing sequence, the troupe arrives at a train station; it is exactly the same scene as the opening one, the same lines are heard; only now it is 1936 . The players are tired, but young, full of hope for the future. However, the viewer knows not only their personal destinies, as Volpi and Barbera state, but also what is in store for them: their political actions fail in the end. Dyer's line of argument on Fassbinder's films can be of use here to propose the following: Angelopoulos's left-wing melancholy manifested in the circularity we have been discussing makes the film incapable of indicating how people can be actively and successfully involved in the processes of change. The circularity of the camera movement and the narrative allegorically also encourages a message of political passivity, and this is embedded not only in the filmmaker's cyclical view of history but also in his emphasis on victims whose political action is ultimately deemed fruitless.

Bordwell (2005) has also extensively explored Angelopoulos use of long takes in which time shifts occur. However, what Bordwell leaves out in his interesting, in-depth analysis is that the shifts in time in The Travelling Players are not random. Angelopoulos carefully orchestrates them. They are all connected to 1952 and Marshal Papagos's victory at the elections. There are five 
shifts in time in the film, sometimes achieved through editing, but more often arranged through the use of long takes. For example, in segment 26, the players walk along a dock. One by one they walk away and leave the frame. With a circular movement, the camera in a long take films the troupe from behind as they walk away. On the soundtrack, megaphone propaganda relating to Marshal Papagos and the 1952 elections is heard. A car enters the frame, and the camera with a pan to the right follows it as it disappears in the distance. Then the camera remains static for a few minutes, giving us an image of the buildings in the street where the car has just passed by, empty of figures now, as we hear the same political information from the megaphone. A car is heard offscreen, clearly approaching, and it eventually enters the frame. It bears the insignia of the German army. The camera follows the car to find a German soldier in the street. It is now 1942, and Greece is under Axis Occupation. In this sequence, a shift in chronology has occurred within a single shot through camera movement.

As mentioned above, all five time shifts in the film are all connected to 1952 and the victory in the elections of Marshal Papagos, whose regime Angelopoulos called a "veiled dictatorship of a field marshal, who was viewed by many Greeks, exhausted by all the catastrophes, as a liberator" (Fainaru 2001, 17). In its mise-en-scène and camera movement, the cyclical connection between the shifts in time in the film and 1952 is the outcome of a narrative that does not treat history as linear and progressive in a Brechtian way. It is not a dialectical narrative with open-endedness. Rather, it is a narrative that treats history as cyclical, one that goes round and round.

The film was shot in 1974 under yet another dictatorship, the Colonels' dictatorship, and distributed in 1975. With the above distinct time movements, the film becomes a left-wing critique of the regime of the Colonels in 1974, indeed an act of resistance on Angelopoulos's part. Yet it is as if for Angelopoulos there is a continuity of political instability and dictatorship in Greece through 1974-as if nothing had changed since 1936. Such a reading of the film shows how The Travelling Players and the filmmaker's distinct cinematic style, despite his use of Brechtian techniques, inflects the Brechtian project. Through his cinematic form-his cyclical camera work and sparing use of medium close-ups, as well as the carefully orchestrated cyclical narrative with long takes at narrative turning points that signal history's repetition-Angelopoulos manages to rewrite Brechtian aesthetics. 


\section{The Hunters}

In Angelopoulos's next feature film, The Hunters, six bourgeois hunters find a dead body in the snow on New Year's Eve of 1977. It is the body of a left-wing guerrilla fighter killed during the Greek Civil War. The body is preserved, and the blood from its wounds is fresh, despite the fact that the civil war ended in 1949. The hunters move the dead body into the hotel where they are staying and place it on a table in the lobby. Each member of the group then speaks of his experience of the civil war.

Like The Travelling Players, The Hunters does not follow a linear narrative: it constantly moves backwards and forwards in time. In general, Angelopoulos's potent cinematic language favors the long take instead of editing/montage to mark temporal and spatial changes (Durgnat 1990; Rutherford 2004; Behzad Ghaderi and Adineh 2010). In both films, though, changes in time happen sometimes through the use of the long take and at others through editing. In The Travelling Players, what is noticeable and important, as argued above, is that these shifts in time are carefully connected to 1952 and Marshal Papagos's victory. In The Hunters, the changes in time occur in the hotel lobby, where the six hunters talk about their experiences of the civil war, in the same room where the dead body of the guerrilla fighter has been placed.

Brecht is of assistance when considering the ideological workings of The Hunters. Brecht argues that in epic theater, "the incidents are historicized and socially set. (The former, of course, occurs above all with present-day incidents: whatever is was not always, and will not always be so. The latter casts a questionable light on the prevailing social order and subjects it to discussion)" $(1965,104)$. Brecht was interested in the behavior of anonymous people and how they react to specific historical situations. He rejected theater that tried to produce an illusion of reality, as we have seen, because he thought that realist theater tended to reproduce the dominant ideology and induce the spectators to identify bourgeois ideologies with reality. Historicizing for Brecht is best achieved with the use of the defamiliarization effects, which in The Hunters, as in The Travelling Players, are evidenced throughout the film. The hunters, even more than the troupe of actors, are not presented psychologically, and this lack of psychological depth in the characters points to the defamiliarization effect. The film, at first glance, encourages the audience not to remain passive but to observe the events from a distance, to contemplate, and respond critically to them. In other words, similar forces to those that we saw in The Travelling Players are in play here, too. Angelopoulos makes use of Brechtian techniques 
and the defamiliarization effects in order to foreground and favor the historical events over the characters themselves as individuals.

As mentioned above, the six hunters tell their stories of the Greek Civil War in turns in a lobby of the Hotel Aigli where they are staying. The film's opening scene, when they find the dead body buried in the snow, neatly hints at their ideological position and social status, which is evident throughout the film, as members of the political right who prospered after the communists' defeat in the civil war and now wish for that history to be laid to rest. The body is still bleeding, though. "This story has ended since 1949. What the hell, I don't understand," one of the hunters says. In the next sequence that takes place in the hotel lobby, the hunters place the body on a table on wheels, thus emphasizing its use as a theatrical prop, and they push it behind a red stage curtain that says: "Happy New Year 1977, Aigli." After one of the hunters phones the police, we are shown shots of them in their rooms upstairs. One of them gets dressed in a hurry, another hastily is packing his suitcase, another one picks up his gun and puts it under his pillow as he lies on the bed next to his wife. They are all upset, afraid. But we do not know why. Next we see them downstairs gathered around the body, where something like a police investigation is set up. The organization of the investigation followed by their flashbacks to events since the end of World War II points to their inability to forget. From the outset, this also begins to explain why they react to the dead body in the manner in which they do. These opening scenes are essential to the film's ideological approach to its subject matter and characters. Significantly, the hunters know that their place in society ensures that the authorities will not deal with them unsympathetically. They are all on the side of the winners.

The film's rather downbeat feel comes from the horrific events that unfolded during the Greek Civil War. The hunters are not presented as bad characters; in fact, they are not presented psychologically at all. The first flashback occurs in the next sequence after the investigation in which the six hunters are looking at the police officer in charge, who is leaving on a boat. The camera stays still on them as they stand on the dock. One of them, Savas, the owner of the hotel, starts walking away from the dock. The camera follows him in a medium shot, when a voice is heard from a megaphone announcing the Marshall Plan and American economic assistance to Greece as he approaches people gathered at the square. We are back in 1949. This first flashback in time that takes place within a long take marks not only the beginning of their return to the past but also the return of the past into the present for the hunters: during his narration discussed below, Savas remembers a group of guerrilla fighters being executed. 
The impact of political forces on the hunters is clearly indicated through the mise-en-scène during Savas's narration and in the flashback sequence that follows, in which Savas (the man who walked away from the dock as the time shifted back to 1949) buys his business licence for the hotel Aigli. Meaningfully, Aigli used to be the military headquarters of the guerrilla fighters during the civil war. In the flashback sequence, we see Savas and his girlfriend visiting the premises; they have bought the place. As they walk around in the kitchen, they glimpse something outside the window. They approach, and the camera shows us, the audience, what they can see: guerrilla fighters being executed. The camera then returns to Savas to show him singing and dancing. A temporal cut shows him dancing to the same song a little later. Only now, the restaurant is open for business and is full with people. Through this scene, Angelopoulos not only shows that the right-wing classes were much better cared for than the communists in Greece in 1949 but also that characters are unable to forget the aftermath of the civil war. In the next sequence, we return to the present, 1977, as the police officer asks Savas if he has anything else to add. He replies no, but his wife intervenes, "You forgot to say that the blood on the wound is still fresh." He signs his statement and sits down. The police officer asks the next hunter to stand up to give his statement as the camera reveals all of them sitting in chairs lined up in front of the dead body.

The pressure and guilt felt by the hunters is most critically and explicitly depicted as one after the other they give their statements to the police officer. However, no questions are ever asked throughout the investigation. The investigation does not aim at producing any results. Through his depiction of the guilt felt by the hunters, on the one hand, and the purposeless investigation that is taking place, on the other, Angelopoulos presents a critique of the bourgeoisie in Greece in his era. One cannot avoid recalling Angelopoulos's comments on his film: "The Hunters reflects how a man of my generation sees Greek history, a history whose continuation blends with the years of my own life. It is a study of the historical conscience of the Greek bourgeoisie. In Greece, the ruling class is afraid of history and, for this reason, hides it. The Hunters starts from this premise" (Angelopoulos, n.d.). The film, as Jameson $(2012,68)$ aptly put it, is "an extraordinary allegory for the persistence of guilt" of the winners of the Greek Civil War, namely, the right. Vasilis Rafailidis in his review of the

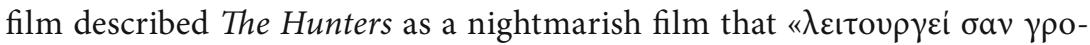
$\theta \iota \dot{\alpha} »$ (functions like a fist) to the jaw for the winners of the civil war (Rafailidis 1977, my translation). However, what is left out from Jameson's and Rafailidis's insightful readings of the film is that The Hunters encourages the audience to take sides with the communists/guerrilla fighters. And while the act of just 
making the two films discussed here may be considered one of resistance on Angelopoulos's part, their form points to pessimism and left-wing melancholy.

In The Hunters, we are meant to take sides. Throughout the film, we witness events as narrated by the six bourgeois hunters. Hence, we witness a right-wing account of history. Nevertheless, this version of events does not prevail. Even as an investigation is set up, the whole purpose of which is to lead nowhere, the film points to the wrongdoings of the political right in the aftermath of the civil war. Significantly, throughout the film the dead body is repeatedly brought into the room only to be placed behind the curtain again. The dead body of the guerrilla fighter is what is prominent throughout the film. Still bleeding after all those years, it provokes the characters' memories-and subsequently their guilt; this in turn evokes the spectator's sympathy for the dead guerrilla fighter's fate. This is paradoxically achieved by Angelopoulos with the use of Brechtian theatricality and V-effects. It is also achieved, as in The Travelling Players, with the cyclical camera work.

The camera performs circular movements throughout The Hunters. As Horton (1997, 69-70) observes, the whole narrative evolves in a circular pattern with the partisan at its center. With the narration of the hotel owner, Savas, followed by the narration of one of the hunters, the ex-communist builder, Fantakis, who signed the anticommunist statement in order to get out of prison after the civil war ended, the ballroom becomes the center of a circular narrative (Makrygiannakis 2008). Towards the end of the film, the hunters and their wives are in the ballroom celebrating New Year's Eve as the camera moves circularly around the tables and the dancing couples. Suddenly, we realize that the guests have all disappeared, leaving the hunters and their wives alone in the ballroom, when the doors unexpectedly burst open, and a group of partisans enter the room pointing their guns at them. The red curtain in front of the stage opens, and the dead partisan, alive, stands up and starts walking towards the other partisans. The hunters and their wives are led outside the hotel and are lined up on the pier facing the camera and the partisans. We can now see what the partisans see.

Are we then allegorically placed in the position of the partisans? The fact that the hunters are taken to the pier is not accidental; after all, this was the place where we saw a group of guerrilla fighters executed during Savas's earlier narration. Next the partisans read a decision of the Revolutionary Army of Greece of 29 August 1949, the date when the Greek Civil War officially ended. They execute the hunters and their wives, and the camera stays still on them lying dead on the pier for a long time. Then, in the same long shot, one after the other, the hunters and their wives get up and go back into the hotel. The partisans are not there anymore. Once in the ballroom again, they take up the 
same positions as before the partisans entered, and they remain still for a few moments until everybody starts to sing and dance as they did before the whole scene with the partisans took place.

This circular scene is characterized by Brechtian stylization and the use of V-effects. We are left with a feeling as if none of what we have just seen has happened. On one level, it is as if the partisans never came into the ballroom, and the hunters' execution by the partisans was a nightmare from which the hunters and their wives have just woken up. On the other hand, the circular narrative and cyclical camera movements here point to the fact that the partisans' struggle, especially their reappearance, did not change anything for the hunters and their wives. After all, at the end of the scene, the hunters continue singing and dancing as if nothing had happened, as if nothing has changed. The partisans' actions in this scene are ultimately rendered in vain, just like the troupe's actions in The Travelling Players. It is this circular narrative and circular camerawork that allegorically marks Angelopoulos's left-wing melancholy and pessimism through the film's cyclical view of history. His left-wing melancholy becomes even clearer in the next scene with which Angelopoulos ends his film.

In this final scene, Angelopoulos takes us with a cut to the snowy landscape we saw in the opening scene. The hunters are on the snow again. The ex-communist Fantakis, who committed suicide earlier in the film, is with them now, alive. They bury the dead body of the guerrilla in the snow as the camera stays still on them in a medium shot. Next we see them walk on the snow to meet two men with hunting dogs as the camera follows them in medium-long shots. They walk towards the men with the dogs, take their positions lined up behind them, the same positions as in the opening scene, and they stay still for a few moments as the camera stays fixed on them. This scene is the same as the opening scene. Then a Royalist song is heard as the camera observes them walk away. The film ends with a theatrical end title card, something Angelopoulos only did in this film.

The film starts and ends with the same scene; it is as if none of what we have just watched happened, nothing new ever will. It is as if the hunters found the body in the snow, and with the prospect and fear of the memories and their guilt that this body could bring back to them, they instantly decided to bury it. It is as if for Angelopoulos in 1977 things have not changed, even 40 years after the Civil War ended, and they never will. The bourgeois hunters bury their guilt, wrongdoings, and memories in the snow with the dead body. This cyclical view of history is melancholic, and The Hunters and The Travelling Players are striking examples of Angelopoulos's left-wing melancholy, despite his use of Brechtian techniques in the films. 


\section{Conclusion}

This article revisited and discussed two critically acclaimed films made by Theo Angelopoulos, The Travelling Players and The Hunters. In particular, I focused on Angelopoulos's cinematic form in conjunction with the theatrical, namely, the Brechtian, aspects of these films, in order to investigate what film can add to the critical category of distanciation. I suggested that despite his left-wing ideology, his use of Brechtian techniques and the historicizing of history, Angelopoulos departs from Brecht aesthetically and ideologically in his manifested melancholy in the films. His melancholy is a left-wing one, particularly in his focus on left-wing characters whose actions are ultimately rendered futile-the characters themselves incapable of making any social and political change.

Angelopoulos's left-wing melancholy is evidenced in his cyclical camera work, careful use of medium close-ups, and cyclical narratives that ultimately render human agency and political action fruitless, since nothing ever changes. The filmmaker's potent cinematic language and the films' carefully orchestrated shifts in time do not offer possible outcomes in a Brechtian dialectical way. Rather, I have suggested that these two films drastically rewrite the Brechtian project by allegorically offering a cyclical-and thus hopelessly recurring-view of history. The Travelling Players and The Hunters are examples of how the visual representation of history and the formal configuration of epic cinema, in the hands of a capable filmmaker, can transform Brechtian aesthetics. Angelopoulos, like Ken Loach, another great melancholic allegorist, seems to be stuck in the past. However, we must note that the filmmaker's left-wing melancholy differs from Pantelis Voulgaris's more recent film about the Greek Civil War, Psyhi Vathia (2009), due to the precise capacity that Angelopoulos possessed not only to ignore but also to abstain from instrumental didacticism.

UNIVERSITY OF SALFORD

\section{NOTES}

Acknowledgements. I am forever in debt to the kind reviewers who looked at this paper. Their comments were invaluable.

${ }^{1}$ The term didactic is used in this paper not in the binary reductive approach that views didacticism as opposed to reflection but rather in conjunction with reflection in the way in which Angela Curran and Olga Taxidou use the term. See Curran 2001 and Taxidou 2008. 
${ }^{2}$ For a comprehensive political, social, and military analysis of the Greek Civil War by a Greek historian, Margaritis's two-volume History of The Greek Civil War (2002) is of great importance. David Close's The Origins of the Greek Civil War (1995) offers a very instructive, non-Greek perspective on the origins of the war and the foreign, mainly British, intervention.

${ }^{3}$ The Travelling Players won the Greek Competition Award for Best Film, Best Director, Best Screenplay (Theo Angelopoulos), Best Actor (Vangelis Kazan), Best Actress (Eva Kotamanidou), Best Cinematography (Giorgos Arvanitis) in the Thessaloniki Film Festival in 1975, the Grand Prize of the Jury in Cannes (FIPRESCI Prize), the Sutherland Trophy for Theo Angelopoulos in the British Film Institute Awards, and the Interfilm Award in the Berlin Film Festival, while in 1980, it won the Kinema Jumpo Award for Best Foreign Language Film in the Awards of the Japanese Academy. The Hunters was nominated for the Palme d'Or in Cannes Film Festival in 1977.

\section{REFERENCES CITED}

Amengual, Barthélémy. 2012. "A Poetic of History." In Theo Angelopoulos, edited by E. Stathi, 27-35. Thessaloniki: Thessaloniki Film Festival Publications.

Angelopoulos, Theo. N.d. "Official Website." Accessed 5 January 2016. http://www .theoangelopoulos.com/hunters.htm.

Behzad Ghaderi, Sohi, and Khojastehpour Adineh. 2010. "Beginning in the End: Poetry of Greek Tragedy in Theo Angelopoulos's Ulysses' Gaze and The Weeping Meadow.” Literature/Film Quarterly 38 (1): 59-72.

Benjamin, Walter. (1931) 1974. "Left-Wing Melancholy (On Erich Kästner’s New Book of Poems)." Screen 15 (2): 28-32.

(1966) 1998. Understanding Brecht. Translated by Anna Bostock. London and New York: Verso.

Bordwell, David. 2005. Figures Traced in Light: On Cinematic Staging. Berkeley and Los Angeles: University of California Press.

Brecht, Bertolt. 1964. Brecht on Theatre: The Development of an Aesthetic. Edited and translated by John Willett. Second edition. London: Methuen.

— 1965. The Messingkauf Dialogues. Translated by John Willett. London: Methuen. 1980. "Against Georg Lukács." In Aesthetics and Politics. Edited and translated by Fredric Jameson, 68-85. London: Verso.

Close, David H. 1995. The Origins of the Greek Civil War. London and New York: Longman.

Curran, Angela. 2001. "Brecht's Criticisms of Aristotle's Aesthetics of Tragedy." Journal of Aesthetics and Art Criticism 59 (2): 167-184.

Durgnat, Raymond. 1990. "The Long Take in Voyage to Cythera: Brecht and Marx vs. Bazin and God." Film Comment 26 (6): 43-46.

Dyer, Richard. 1976. “Reading Fassbinder's Sexual Politics.” In Fassbinder, edited by T. Rayns, 54-64. London: BFI.

Fainaru, Dan, ed. 2001. Theo Angelopoulos: Interviews. Jackson: University Press of Mississippi. Freud, Sigmund. 1917. "Mourning and Melancholia." In The Standard Edition of the Complete Psychological Works of Sigmund Freud. Vol. 14, (1914-1916): On the History of the 
Psycho-Analytic Movement, Papers on Metapsychology and Other Works, edited by James Strachey, Anna Freud, Alix Strachey, and Alan Tyson, 237-258. London: Hogarth PressThe Institute of Psycho-Analysis.

Horton, Andrew. 1997. The Films of Theo Angelopoulos: A Cinema of Contemplation. Princeton: Princeton University Press.

Jameson, Fredric. 1980. Aesthetics and Politics. London: Verso.

- 2012. "The Past as History, the Future as Form." In Theo Angelopoulos, edited by E. Stathi, 65-86. Thessaloniki: Thessaloniki Film Festival Publications..

Jordan, Isabelle. 2000. “For An Epic Theatre.” In Theo Angelopoulos, edited by E. Stathi, 232-240. Athens: Kastaniotis.

Karalis, Vrasidas. 2006. “The Disjunctive Aesthetics of Myth and Empathy in Theo Angelopoulos' Ulysses Gaze." Literature \& Aesthetics 16 (2): 252-268.

Makrygiannakis, Evangelos. 2008. “The Films of Theo Angelopoulos: A Voyage in Time.” PhD diss., University of Edinburgh.

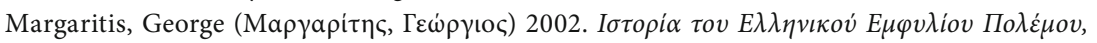
1946-1949 [History of the Greek Civil War, 1946-1949]. 2 volumes. Athens: Bibliorama.

Mumford, Meg. 2009. Bertolt Brecht. New York: Routledge.

Pensky, Max. 1993. Melancholy Dialectics: Walter Benjamin and the Play of Mourning. Amherst: University of Massachusetts Press..

Polan, Dana. 1985. “A Brechtian Cinema? Towards a Politics of Self-Reflexive Film.” In Movies and Methods, Vol. 2, edited by B. Nichols, 661-672. Berkeley and Los Angeles: University of California Press.

Quintana, Ángel. 2012. “The Image-Symbol.” In Theo Angelopoulos, edited by E. Stathi, 156-161. Athens: Thessaloniki Film Festival Publications.

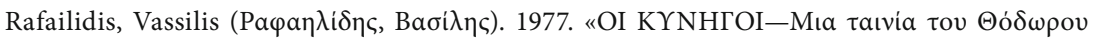
A $\gamma \gamma \varepsilon \lambda$ ó

Rollet, Sylvie. 2012. “Theater versus Image.” In Theo Angelopoulos, edited by E. Stathi, 156-161. Athens: Thessaloniki Film Festival Publications.

Rutherford, Anne. 2004. "Precarious Boundaries: Affect, Mise en scène, and the Senses in Angelopoulos's Balkans Epic.” Senses of Cinema 31. Accessed on 22 July 2016. http:// sensesofcinema.com/2004/feature-articles/angelopoulos_balkan_epic/.

Taxidou, Olga. 2008. "Machines and Models for Modern Tragedy: Brecht/Berlau, Antigone-Model 1948.” In Rethinking Tragedy, edited by R. Felski, 241-262. Baltimore: Johns Hopkins University Press.

Tyson, Peter K. 2012. "Berlin Alexanderplatz: Brecht/Döblin/Fassbinder-In Search of Synthesis.” Neophilologus 96: 287-300.

Van Steen, Gonda. 2013. “The Story of Ali Retzo: Brechtian Theatre in Greece under the Military Dictatorship." Journal of Greek Modern Studies 31 (1): 85-115.

Volpi, Gianni, and Alberto Barbera. 2012. "Notes on the Formal Structure of The Travelling Players." In Theo Angelopoulos, edited by E. Stathi, 156-161. Athens: Thessaloniki Film Festival Publications.

Walsh, Martin. 1981. The Brechtian Aspect of Radical Cinema. Edited by K. M. Griffiths. London: BFI.

White, John. 2004. Bertolt Brecht's Dramatic Theory. New York: Camden House. 